\title{
Isolation and characterization of bioactive protein from green algae Halimeda macrobola acting as antioxidant and anticancer agent
}

\author{
Ahyar Ahmad ${ }^{1,2, ~ *, ~ H a n a p i ~ U s m a n ~}{ }^{1,2}$, Hasnah Natsir ${ }^{2}$, Abdul Karim ${ }^{2}$ \\ ${ }^{1}$ Laboratory of Research Centre and Developing of Sciences, Mathematic and Natural Science Faculty, Hasanuddin University, Jl. Perintis \\ Kemerdekaan KM 10, Makassar 90245, Indonesia \\ ${ }^{2}$ Laboratory of Biochemistry, Chemistry Department, Mathematic and Natural Science Faculty, Hasanuddin Univesity, Jl. Perintis \\ Kemerdekaan KM 10, Makassar 90245, Indonesia
}

\section{Email address:}

ahyarahmad@gmail.com (A. Ahmad)

To cite this article:

Ahyar Ahmad, Hanapi Usman, Hasnah Natsir, Abdul Karim. Isolation and Characterization of Bioactive Protein from Green Algae Halimeda macrobola Acting as Antioxidant and Anticancer Agent. American Journal of Biomedical and Life Sciences. Vol. 2, No. 5, 2014, pp. 134-140. doi: $10.11648 /$ j.ajbls.20140205.15

\begin{abstract}
A protein fraction isolated from green algae Halimeda macrobola taken from the sea of Selayar and Kapoposang Island in South Sulawesi was tested for antioxidant and anticancer properties. The protein was isolated using buffer Tris (hydroxymethyl) amino methane. Initial purification of protein was conducted by using the fractionation method with ammonium sulphate, followed by dialysis process. Protein concentration was determined by Lowry method. Antioxidant assay was done by using DPPH method and anticancer activity test by Brine Shrimp Lethality Test (BSLT) method. Anticancer activity was further confirmed by antimitotic test using urchin zygote cells. The results showed that the protein concentration of the crude extract was $0.920 \mathrm{mg} / \mathrm{mL}$. The highest concentration of protein fractions was indicated by the fraction $40-60 \%$, with 1.015 $\mathrm{mg} / \mathrm{mL}$. The strong antioxidant activity was shown in the protein fraction of $0-20 \%$ saturation with $\mathrm{IC}_{50}$ values of 0.110 $\mathrm{mg} / \mathrm{mL}$. The highest activity in the anticancer tests was shown in fractions $0-20 \%$ saturation with $\mathrm{LC}_{50}$ values of $0.29 \mu \mathrm{g} / \mathrm{mL}$ and $\mathrm{IC}_{50}$ value of $53.80 \mu \mathrm{g} / \mathrm{mL}$. The protein fraction $0-20 \%$ saturation had a potential to be developed as antioxidant and anticancer agent. These results demonstrate that inexpensive green algae Halimeda macrobola could be a new alternative to produce antioxidant and anticancer proteins.
\end{abstract}

Keywords: Green Algae, Protein Fraction, Toxicity, Antioxidant, Anticancer

\section{Introduction}

Indonesia is known as an archipelago, where the Indonesian sea area is larger than its land area. The extensive entire territory of Indonesia is 5 millions $\mathrm{km}^{2}$ consisting of 1.9 million $\mathrm{km}^{2}$ land area, 0.3 million $\mathrm{km}^{2}$ territorial sea, and the inland waters or the archipelagic waters covering an area of 2.8 millions $\mathrm{km}^{2}$. This means that the entire ocean in Indonesia amounts to 3.1 millions $\mathrm{km}^{2}$, or about $62 \%$ of the entire territory of Indonesia ${ }^{[1] .}$

Noticing the area of Indonesia is largely a region of the ocean, our future will be determined largely on our ability to utilize marine resources. In the ocean, variety of marine biota such as aquatic animals and aquatic plants are scattered. The diversity of marine biota in Indonesia is very large and is a potential source of wealth. It provides us many opportunities to take advantage of the aquatic animals and plants, as well as a challenge for us to explore outcomes of the sea.

Algae is one of the potential Indonesian natural resources. Algae consists of macroalgae and microalgae. In Indonesia, some types of macroalgae such as Halimeda macrobola, Gracilaria sp., Sargassum sp., Chlorella sp., and Spirulina sp., were researched and were found to have a high economic value $^{[2]}$

Studies of the active components in algae grew in line with the success of isolated natural products. Researchers have reported the uses of algae as agents for antibacterial, anthelmintic, anticancer, antiulcer, lowering blood pressure, lowering cholesterol, preventing stroke, treating goiter, iron deficiency, and blood deficiency diseases ${ }^{[2]}$.

Cancer is the uncontrolled growth and spread of cells. It can 
affect almost any part of the body. The growths often invade surrounding tissue and can metastasize to distant sites. Metastasis is a major cause of cancer deaths. Cancer can be cured by surgery, radiotherapy or chemotherapy, especially if detected early ${ }^{[3]}$.

Cancer is a leading cause of death worldwide, accounting for 7.6 million deaths (around 13\% of all deaths) in 2008 . Lung, stomach, liver, colon and breast cancer cause the most cancer deaths each year. About $30 \%$ of cancer deaths are due to the five leading behavioral and dietary risks: high body mass index, low fruit and vegetable intake, lack of physical activity, tobacco use, and alcohol use. Deaths from cancer worldwide are projected to continue rising, with an estimated 13.1 million deaths in $2030^{[3]}$.

The number of deaths caused by cancer, caught the attention of scientists to examine potential compounds as anticancer agents. In recent years, many researchers glanced natural materials as a target test material, where its presence is abundant in nature besides, the use of natural materials can minimize side effects.

The compounds that have been isolated from algae as anticancer agents include Sesquiterpenoid from algae Caulerpata xifolia, Kahalalide F from algae Bryopsis, peptide compounds from algae Chlorella vulgaris, $\beta$-carotene from algae Rhodymenia pseudopalmata, Eucheuma Serra Agglutinin (ESA) a lectin compound from algae Eucheuma serra, protein fractions from algae Gelidium amansii and Turbinaria decurrens, and protein extracts from endophytic fungus Xylariapsidii KT30 isolated from red algae Kappaphycu salvarezii ${ }^{[4,5,6,7]}$.

So far the research area has not explored the bioactive compounds of protein from green algae, particularly Halimeda macrobola, and its value as antioxidant and anticancer drug raw materials, so a broader exploration towards the potential of the green algae is considered necessary.

This study was conducted to isolate and identify the bioactive compounds of proteins from green algae Halimeda macrobola from Selayar and Kapoposang Island, Indonesia teristerial. The isolation of bioactive proteins from green algae was obtained through a series of processes of extraction, fractionation and purification. The antioxidant assay was done by using DPPH method.The toxicity of the obtained protein fractions was tested using BSLT (Brine Shrimp Lethality Test) methods against larvae shrimp Artemia salina Leach and confirmed by antimitotic testing using urchin zygote cells.

\section{Materials and Methods}

\subsection{Materials}

The materials used in this study included the green algae Halimeda macrobola, buffer A (Tris- $\mathrm{HCl} 0.1 \mathrm{M} \mathrm{pH} \mathrm{8.3;} \mathrm{NaCl}$ $2 \mathrm{M} ; \mathrm{CaCl}_{2} 0.01 \mathrm{M}$; $\beta$-mercaptoetanol 1\%; Triton X-100 $0.5 \%$ ), buffer B (Tris-HCl0.1 M pH 8.3; $\mathrm{NaCl} 0.2 \mathrm{M} ; \mathrm{CaCl}_{2}$ $0.01 \mathrm{M}$ ), buffer $\mathrm{C}$ (Tris-HCl0.01 M pH 8.3; $\mathrm{NaCl} 0.2 \mathrm{M}$;
$\mathrm{CaCl}_{2} 0.01 \mathrm{M}$ ), distilled water, BSA (Bovine Serum Albumin), ammonium sulphate, Lowry A solution (Follin ciocalteusin phosphotungstat-phosphomolybdat acid solution with distilled water $1: 1)$, Lowry B solution $\left(\mathrm{Na}_{2} \mathrm{CO}_{3} 2 \%\right.$; $\mathrm{NaOH} 0.1$ $\mathrm{N} ; \mathrm{CuSO}_{4} .5 \mathrm{H}_{2} \mathrm{O} 1 \%$, Sodium potassium tartrate $2 \%$ ), $\mathrm{HCl} 1$ M, sea water, eggs shrimp Artemia salina Leach, Vincristine, males and females urchin (Tripneustes gratilla Linn.), and $\mathrm{KCl} 10 \%$.

\subsection{Sample Preparation}

The isolation of bioactive proteins from green algae Halimeda macrobola used a procedure modified from previous methods ${ }^{[6,8]}$ as follows: The selected algae were cut into small pieces and weighed as much as $500 \mathrm{~g}$ fresh weight, homogenized by using $500 \mathrm{~mL}$ buffer A solution in a waring blender, then filtered through a filter cloth. The filtrate was freeze-thawed 2-3 times and centrifuged at $6000 \mathrm{rpm}, 4^{\circ} \mathrm{C}$ for 20 minutes. The supernatant (whole extracts) obtained was stored in a refrigerator until tested for antioxidant and anticancer activity and further purification steps.

\subsection{Fractionation}

The crude extract was fractionated by using ammonium sulphate at saturation level of $0-20 \%, 20-40 \%, 40-60 \%$, and $60-80 \%$.

\subsection{Dialysis}

The precipitates obtained after fractionation at each saturation level of ammonium sulphate were dissolved in 10 $\mathrm{mL}$ buffer $\mathrm{B}$ and subsequently dialyzed in buffer $\mathrm{C}$. The protein fractions was put into selophan pocket (Sigma) and placed in a beaker glass containing the buffer $\mathrm{C}$ solution. The dialysis was continued until the buffer solution became colorless.

\subsection{Determination of Protein Concentration}

The protein concentration of each fraction was determined by Lowry method using bovine serum albumin (BSA) solution as a standard ${ }^{[9]}$.

\subsection{Antioxidant Assay Using DPPH Method (1,1-Diphenyl-2-Pycrylhydrazyl)}

The protein fractions $0-20 \%$ saturation with various concentrations of $0.1 \mathrm{mg} / \mathrm{mL}, 0.2 \mathrm{mg} / \mathrm{mL}, 0.3 \mathrm{mg} / \mathrm{mL}, 0.4$ $\mathrm{mg} / \mathrm{mL}$ and $0.5 \mathrm{mg} / \mathrm{mL}$, were put into a $5 \mathrm{~mL}$ volumetric flask, and $0.5 \mathrm{~mL}$ of $0.1 \mathrm{mM}$ DPPH solution was added. The volume was filled up to $5 \mathrm{~mL}$, and incubated at $37^{\circ} \mathrm{C}$ for $30 \mathrm{~min}$. The absorbance was measured at the maximum wavelength 450 $\mathrm{nm}$. Same treatment was performed on protein fraction $20-40 \%, 40-60 \%$, and $60-80 \%$ saturation. The blank absorbance measurement was also performed. The results of the antioxidant determination were compared to the ascorbic acid as a positive control. The value of the antioxidant activity was calculated using the formula ${ }^{[10,11]}$ : 
$\%$ Antioxidant activity $=\frac{\text { Absorbance control }- \text { Absorbance sample }}{\text { Absorbance control }} \times 100 \%$

\subsection{Toxicity Test Using Brine Shrimp Lethality Test (BSLT) Method}

\subsubsection{Preparation of Shrimp Larvae}

The shrimp eggs were put into containers of sea water for hatching, and aerated under 40-60 watt in candescent lamp. The hatching temperature was maintained in range of 25-30 ${ }^{\circ} \mathrm{C}$ with light for 48 hours. After the eggs hatched, shrimp larvae were taken to be tested ${ }^{[12]}$.

\subsubsection{Implementation Test}

The toxicity tests using Brine Shrimp Lethality Test (BSLT) method used a procedure modified from the previous reports ${ }^{[13,14]}$. The test compounds were made in concentration of $1 \mu \mathrm{g} / \mathrm{mL}, 10 \mu \mathrm{g} / \mathrm{mL}$, and $100 \mu \mathrm{g} / \mathrm{mL}$, and were placed in 3 vials. Ten shrimp larvaes were inserted into the test compound, sea water was added to $5 \mathrm{~mL}$, and was stored under illumination for 24 hours. The same treatment was done using buffer B without sample (solvent) as a negative control and Vincristine as a positive control. Next, the dead and live larvae were observed and calculated. The $\mathrm{LC}_{50}$ value was determined by using Probit analysis. The mortality percentage of shrimp larvae could be determined by the Abbott formula ${ }^{[15]}$.

$$
\% \text { Mortality }=\frac{\sum \text { test larvae were dead }-\sum \text { control larvae were dead }}{\sum \text { test larvae }} \times 100 \%
$$

\subsection{Antimitotic Test of Urchin Zygote Cells}

\subsubsection{Urchin Egg and Sperm Cells Preparation}

The induction of male and female urchins was performed by injecting $5 \mathrm{~mL}$ of $10 \% \mathrm{KCl}$ into the gonad section. The milky sperm and golden yellow egg cells were stored in different containers. A total of $1 \mathrm{~mL}$ sperm and $5 \mathrm{~mL}$ of egg cells was put into a container that contained $50 \mathrm{~mL}$ of protozoa-free seawater for fertilization process.

\subsubsection{Test Samples Preparation}

The high toxicity green algae Halimeda macrobola fraction in BSLT test was made in a concentration of 1,10 , and 100 $\mu \mathrm{g} / \mathrm{mL}$. The negative control was made by using buffer B and a positive control was made by using Vincristine with a concentration of 1,10 , and $100 \mu \mathrm{g} / \mathrm{mL}$.

\subsubsection{Implementation Test}

Seawater was added to the test samples in the eppendorff tube to suffice the final volume to $1 \mathrm{~mL}$ and $100 \mu \mathrm{L}$ zygotes was added into the tube after 10 minutes fertilization. Each test sample and control were repeated for 2 times, then stored at a temperature of $15-20{ }^{\circ} \mathrm{C}$ with intermittent shaking. The cells observations were carried out after 2 hours of incubation by using a light microscope. The $\mathrm{IC}_{50}$ values were calculated by using Probit-log concentration graph. The percentage inhibition of urchin zygote cells could be calculated by the following formula ${ }^{[16]}$.

$$
\% \text { Mortality }=\frac{\sum \text { test larvae were dead }-\sum \text { control larvae were dead }}{\sum \text { test larvae }} \times 100 \%
$$

\section{Results and Discussion}

\subsection{Isolation of Protein from Algae}

The samples of green algae Halimeda macrobola used in this study were obtained from Selayar and Kapoposang Island, Indonesia. The process of cell lysis was done by homogenizing using buffer A solution, to break the cells of green algae so that the proteins contained in the cell could be dissolved in buffer solution. The presence of Triton X-100 $0.5 \%$ in buffer A served to help the process of cell lysis by pressing plasma chemically so that the presence of the physical friction cell would be split. The freeze-thaw process was employed to enhance cell lysis.

The separation of the precipitate and the supernatant was carried out through a process of centrifugation. The principle of a centrifuge which separates the substances was based on the molecular density by providing centrifugal force so that the heavier substance would be at the bottom, while the lighter substance would be at the top.
The algae proteins isolation was carried out at low temperatures of $0-4{ }^{\circ} \mathrm{C}$ by using buffer A because the protein was strongly influenced by environmental conditions. Therefore, the temperature and $\mathrm{pH}$ of the solution should be maintained so as not to damage the protein.

The pre-purification of proteins was done by using ammonium sulphate fractionation and then dialyzed by using a selophan membrane. The fractionation aimed to separate proteins based on their solubility differences in water. The protein fractionation process was carried out by the addition of ammonium sulphate at saturation levels of $0-20 \%, 20-40 \%$, $40-60 \%$, and $60-80 \%$. The protein precipitation used the principle of salting out, where water binds with ammonium sulphate.

The addition of ammonium sulphate salt from low to high concentration led to different types of protein buildup. The solubility of proteins in water were different and the addition of salt to a certain concentration led to precipitation of particular proteins. The fractionation using ammonium sulphate produced proteins with high salt content, therefore 
salts remaining in the precipitation process were separated by dialysis in buffer $\mathrm{C}$ solution using a semipermeable membrane (selophan pocket). The dialysis method is the best known method to eliminate contaminant molecules, such as salt or other ion and monomer compounds. The dialysis process was performed at $4{ }^{\circ} \mathrm{C}$ to prevent damage of the pure protein. The proteins produced in the process of dialysis were pure proteins free from ammonium sulphate.

\subsection{Determination of Protein Concentration}

The determination of protein concentration was done by using the Lowry method, which is based on the reaction of proteins with fosfotungstate-fosfomolibdate acid at the alkaline atmosphere and would give a blue color where the intensity depended on the concentration of the protein. Furthermore, the absorbance measurements were performed using UV-Vis Spectrophotometry.

Based on the measurements that have been done, the concentration and the total of proteins in green algae Halimeda macrobola crude extract and protein fractions at different levels of saturation of ammonium sulphate fractionation are given in Table 1.

Table 1. The determination of the concentration and the total amount of proteins in the crude extract and protein fractions at different levels of saturation of ammonium sulphate in green algae Halimeda macrobola.

\begin{tabular}{lllll}
\hline No. & Protein fraction & Volume of fraction $(\mathbf{m L})$ & Protein concentration $(\mathbf{m g} / \mathbf{m L})$ & Protein total $(\mathbf{m g})$ \\
\hline 1. & Crude extract & 550 & 0.920 & 393.80 \\
2. & $0-20 \%$ & 10 & 0.716 & 7.16 \\
3. & $20-40 \%$ & 10 & 0.851 & 8.51 \\
4. & $40-60 \%$ & 10 & 1.015 & 10.15 \\
5. & $60-80 \%$ & 10 & 0.862 & 8.62 \\
\hline
\end{tabular}

As seen in Table 1, protein concentration of the crude extract was $0.920 \mathrm{mg} / \mathrm{mL}$ and the total amount of protein was $393.8 \mathrm{mg}$ in $550 \mathrm{~mL}$ crude extract. The highest protein concentration was found in protein fraction of $40-60 \%$ at $1.015 \mathrm{mg} / \mathrm{mL}$, and the lowest concentration of the protein in fraction $0-20 \%$ at $0.716 \mathrm{mg} / \mathrm{mL}$. The different concentration of each fraction showed that different types of protein were built up. Some proteins had different solubility in water. The higher the solubility, the lesser protein was built up.

\subsection{Antioxidant Assay Using DPPH Method}

The antioxidant assay using this method is based on the disappearance of the purple color due to reduced DPPH by antioxidants. The color intensity of the test solution was measured by UV-Vis Spectrophotometry ${ }^{[10,11]}$. The results of the antioxidant activity measurement of each protein fraction of green algae Halimeda macrobola with various concentration could be analyzed based on the results of the absorbance measurement at the maximum wavelength (510 $\mathrm{nm}$ ) and the control absorbance at 0.518 (Figure 1).

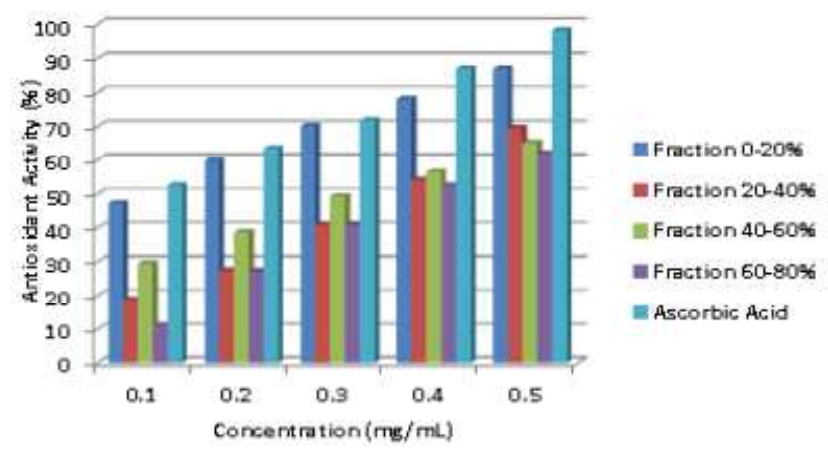

Figure 1. The antioxidant activity of the protein fractions and the ascorbic acid as positive control.

The highest antioxidant activity was obtained in the protein fraction of $0-20 \%$ at a concentration of $0.1 \mathrm{mg} / \mathrm{mL}$ of $47.29 \%$ and at concentration of $0.5 \mathrm{mg} / \mathrm{mL}$ of $87.06 \%$.The lowest antioxidant activity was found in protein fraction $60-80 \%$ with a concentration of $0.1 \mathrm{mg} / \mathrm{mL}$ of $11.19 \%$ and $62.16 \%$ at concentration of $0.5 \mathrm{mg} / \mathrm{mL}$. The positive control ascorbic acid had much greater antioxidant activity than all the protein fractions at a concentration of $0.1 \mathrm{mg} / \mathrm{mL}$ of $52.57 \%$ and $98.26 \%$ at a concentration of $0.5 \mathrm{mg} / \mathrm{mL}$.

Based on the obtained data, the linear regression equation that stated the relationship between the concentration of the test solution ( $\mathrm{x}$ ) with the antioxidant activity (y) was obtained and the $\mathrm{IC}_{50}$ value which was the required concentration of test solution to neutralize $50 \%$ of $\mathrm{DPPH}^{[11]}$ was calculated. The $\mathrm{IC}_{50}$ values were inversely proportional to the antioxidant activity of a compound contained in the protein fraction and ascorbic acid. The smaller the $\mathrm{IC}_{50}$ values, the greater the antioxidant activities. According to the data calculations that have been performed, the $\mathrm{IC}_{50}$ values were obtained as shown in Table 2.

Table 2. The Values of $I C_{50}$ from each protein fraction and ascorbic acid as positive control

\begin{tabular}{l|ll}
\hline No & Sample Solution & IC $_{\mathbf{5 0}}(\mathbf{m g} / \mathbf{m L})$ \\
\hline 1. & Protein Fraction 0-20\% & 0.110 \\
2. & Protein Fraction $20-40 \%$ & 0.360 \\
3. & Protein Fraction 40-60\% & 0.323 \\
4. & Protein Fraction $60-80 \%$ & 0.387 \\
5. & Ascorbic Acid & 0.085 \\
\hline
\end{tabular}

Table 2 above showed the antioxidant activity contained in each of the protein fraction. However, based on the obtained $\mathrm{IC}_{50}$ values, the protein Fraction of $20-40 \%$, 40-60\%, and $60-80 \%$ saturation had weak antioxidant activities with the $\mathrm{IC}_{50}$ values of $0.360 \mathrm{mg} / \mathrm{mL}, 0.323 \mathrm{mg} / \mathrm{mL}$, and $0.387 \mathrm{mg} / \mathrm{mL}$, whereas the protein fraction of $0-20 \%$ saturation and ascorbic acid as positive control had strong antioxidant activities with the $\mathrm{IC}_{50}$ values of $0.110 \mathrm{mg} / \mathrm{mL}$ and $0.085 \mathrm{mg} / \mathrm{mL}$, respectively. According to Molyneux, 2004 ${ }^{[11]}$, a compound 
could be a powerful antioxidant if it had $\mathrm{IC}_{50}$ values of less than $0.150 \mathrm{mg} / \mathrm{mL}$.

\subsection{Anticancer Activity Test of the Protein Fraction from Green Algae Halimeda macrobola}

The anticancer activity test of the protein fraction from green algae Halimeda macrobola was performed by using preliminary test, Brine Shrimp Lethality Test (BSLT) method against larvae shrimp Artemia salina Leach, and was further confirmed by antimitotic test of the urchin Tripneustes gratilla Linn zygote cells.

\subsubsection{Toxicity Test against Artemia Salina Leach}

The determination of $\mathrm{LC}_{50}$ values was conducted to determine the toxic effects of the protein fraction in the green algae Halimeda macrobola. The observations were made after 24 hours by counting the number of shrimp larvae mortality, furthermore $\mathrm{LC}_{50}$ values were determined using probit-log concentration graph. The $\mathrm{LC}_{50}$ values indicated the magnitude concentration of the sample that could lead to $50 \%$ death of test animals. The $\mathrm{LC}_{50}$ value of each protein fraction in the green algae Halimeda macrobola and Vincristine are given in Figure 2.

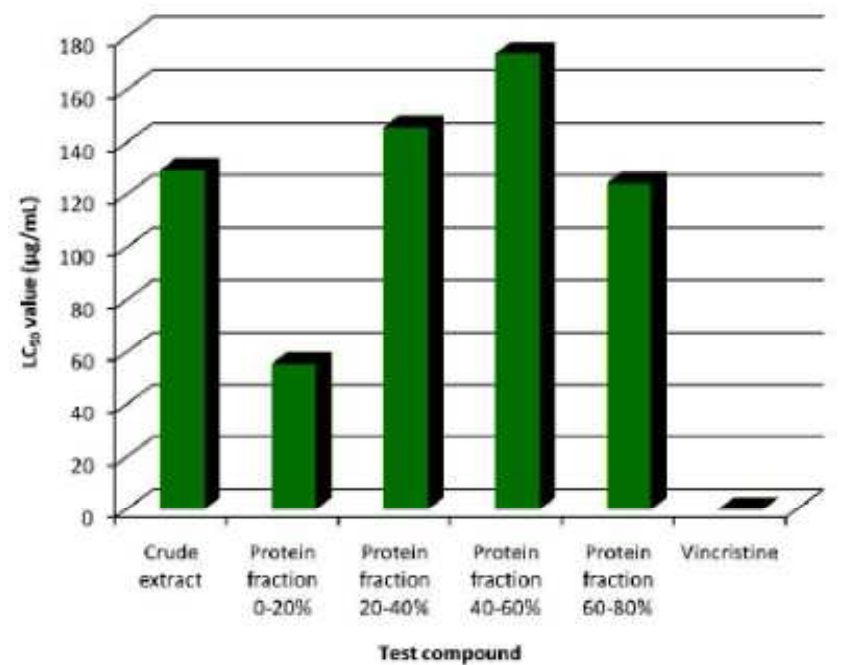

Figure 2. Diagram of $L C_{50}$ values against larvae shrimp (Artemia salina Leach) of green algae Halimeda macrobola protein fractions and Vincristine (positive control).

The obtained $\mathrm{LC}_{50}$ values (Figure 2 ) showed that the crude extract and protein fractions in green algae Halimeda macrobola were toxic. According to Marliyana, et. al., 2012 $2^{[7]}$, a substance was active or toxic if its $\mathrm{LC}_{50}$ value: $<1.000$ $\mathrm{mg} / \mathrm{mL}$ for the extract and $<30 \mathrm{mg} / \mathrm{mL}$ for a pure compound. Based on Figure 2, the protein fractions of $0-20 \%$ saturation had the highest toxicity with $\mathrm{LC}_{50}$ values of $55.62 \mu \mathrm{g} / \mathrm{mL}$, whereas the protein fractions of $40-60 \%$ saturation had the lowest toxicity with $\mathrm{LC}_{50}$ values of $173.82 \mu \mathrm{g} / \mathrm{mL}$.

\subsubsection{Antimitotic Test against Urchin Zygote Cells}

The most toxic protein fractions were further tested with antimitotic activity against urchin zygote cells, Vincristine drug was used as a positive control. After 2 hours of incubation, the divided and undivided zygote cells urchin Tripneustes gratilla Linn were counted. The division inhibition of urchin Tripneustes gratilla Linn zygote cells can be seen in Figure 3.

Table 3. The calculation results of the urchin Tripneustes gratilla Linn zygote cells division inhibition on protein fractions $0-20 \%$ saturation.

\begin{tabular}{lll}
\hline No. & $\begin{array}{l}\text { Concentration of protein } \\
\text { fraction } \mathbf{0 - 2 0} \% \mathbf{(} \mathbf{\mu} / \mathbf{m L})\end{array}$ & $\begin{array}{l}\text { Cells division Inhibition } \\
\mathbf{( \% )}\end{array}$ \\
\hline 1. & 1 & 18.16 \\
2. & 10 & 36.0 \\
3. & 100 & 55.0 \\
\hline
\end{tabular}

The total of divided and undivided zygote cells were calculated and their percentage of inhibition were determined. The calculation results of the urchin Tripneustes gratilla Linn zygote cells division inhibition on protein fractions $0-20 \%$ saturation are shown in Table 3.

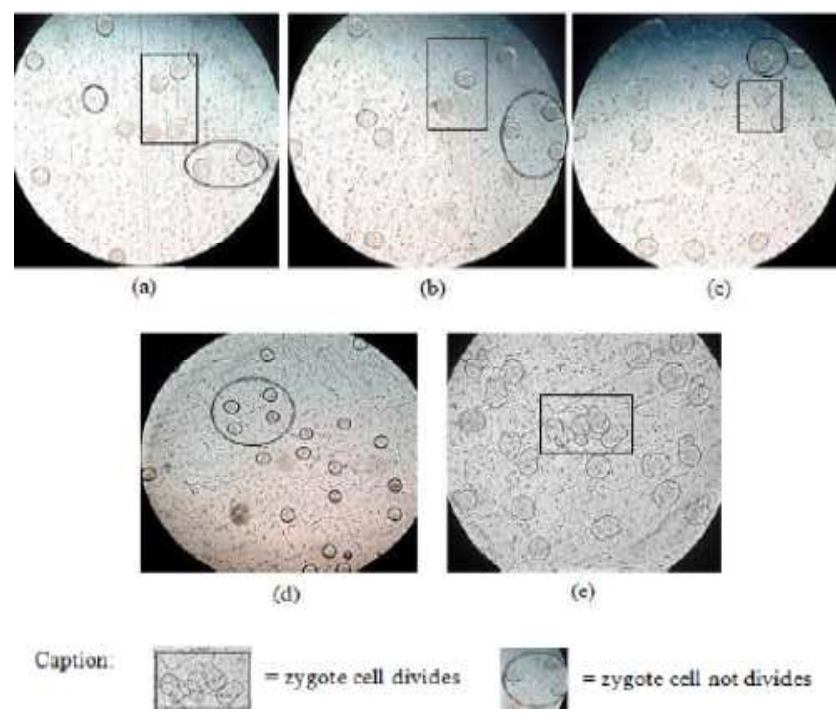

Figure 3. The division of urchin Tripneustes gratilla Linn. zygote cells with antimitotic test method (a) protein fraction $0-20 \%$ of $100 \mu \mathrm{g} / \mathrm{mL}$, (b) protein fraction $0-20 \%$ of $10 \mu \mathrm{g} / \mathrm{mL}$, (c) protein fraction $0-20 \%$ of $1 \mu \mathrm{g} / \mathrm{mL}$, (d) Vincristine (positive control), (e) Solvent (negative control).

The inhibition values of protein fractions $0-20 \%$ saturation at concentration of $1 \mu \mathrm{g} / \mathrm{mL}$ was $18.16 \%$ and at concentration of $10 \mu \mathrm{g} / \mathrm{mL}$ was $36.0 \%$. This suggested that the inhibition values of cells division were less than $50 \%$ due to the low given concentration, where the numbers of divided cells were higher than the undivided cells. However, at concentration of $100 \mu \mathrm{g} / \mathrm{mL}$ the inhibition value of cell division reached $55.0 \%$, more than $50 \%$. Higher the concentrations used, higher were the inhibition values of the cells.

In this method, the cells division inhibitory activity was calculated as $\mathrm{IC}_{50}$ values, the concentrations that could inhibit cells division by $50 \%$. The obtained inhibition of cells division datas were subsequently processed using Probit-log concentration graph method to obtain $\mathrm{IC}_{50}$ values. The $\mathrm{IC}_{50}$ values of protein fractions $0-20 \%$ saturation and Vincristine as a positive control are given in Table 4 . 
Table 4. The calculation results of the $I C_{50}$ values of division inhibition of urchin Tripneustes gratilla Linn zygote cells.

\begin{tabular}{llll}
\hline No. & Test compound & IC $_{\mathbf{5 0}}$ value $(\boldsymbol{\mu g} / \mathbf{m L})$ \\
\hline 1. & Protein fraction & $0-20 \%$ & 53.80 \\
2. & Vincristine & 0.36 \\
\hline
\end{tabular}

Figure 4 showed that the $\mathrm{IC}_{50}$ value of the protein fraction $0-20 \%$ saturation was $53.80 \mu \mathrm{g} / \mathrm{mL}$. According to Weerapreyakul et al., $2012^{[12]}$, the level of cytotoxicity of an extract is based on its $\mathrm{IC}_{50}$ values: $<10 \mu \mathrm{g} / \mathrm{mL}$ (very strong), $10-100 \mu \mathrm{g} / \mathrm{mL}$ (strong), $100-500 \mu \mathrm{g} / \mathrm{mL}$ (moderate). This indicated that the protein fraction $0-20 \%$ had potential as antimitotic agents. If it was viewed from the similarities of nature with Vincristine which had $\mathrm{IC}_{50}$ value of $0.36 \mu \mathrm{g} / \mathrm{mL}$, the protein fraction $0-20 \%$ saturation could be potential to be developed as an alternative anticancer agent.

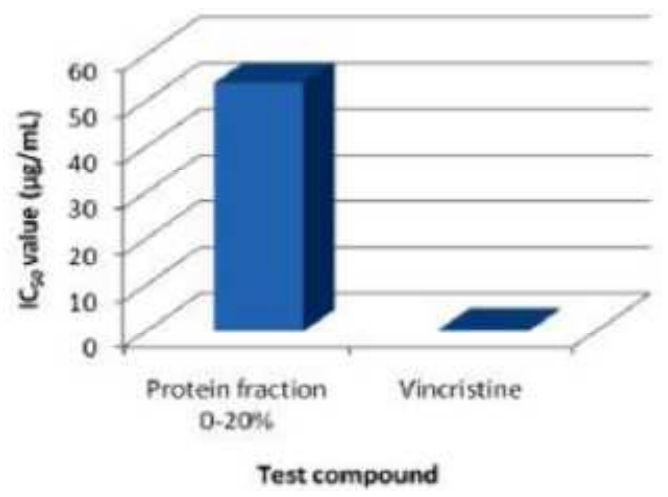

Figure 4. Diagram of $I C_{50}$ values of division inhibition of the urchin Tripneustes gratilla Linn zygote cells by protein fractions $0-20 \%$ saturation and Vincristine (positive control).

\section{Conclusions}

Bioactive protein compounds were isolated from the green algae Halimeda macrobola through series of processes of extraction, fractionation and prepurification by dialysis. The obtained protein concentration of the crude extract of green algae Halimeda macrobola was $0.92 \mathrm{mg} / \mathrm{mL}$.

The strong antioxidant activity was contained in the protein fraction of $0-20 \%$ saturation with $\mathrm{IC}_{50}$ values of $0.110 \mathrm{mg} / \mathrm{mL}$, whereas weak antioxidant activities were shown by protein fraction of $20-40 \%, 40-60 \%$ and $60-80 \%$ saturation with $\mathrm{IC}_{50}$ values of $0.360 \mathrm{mg} / \mathrm{mL}, 0.323 \mathrm{mg} / \mathrm{mL}$, and $0.387 \mathrm{mg} / \mathrm{mL}$, respectively.

The strongest activity of protein fractions from green algae Halimeda macrobola presented was seen in fractions $0-20 \%$ with $\mathrm{LC}_{50}$ values of $55.62 \mu \mathrm{g} / \mathrm{mL}$ against the larvae shrimp Artemia salina Leach, and the $\mathrm{IC}_{50}$ value of $53.80 \mu \mathrm{g} / \mathrm{mL}$ against urchin Tripneustes gratilla Linn. zygote cells. The protein fraction of $0-20 \%$ saturation had potential to be developed as an alternative antioxidant and anticancer agents.

Purification and characterization of amino acids contained in the isolated proteins should be performed in the future research. In addition research is needed to perform the anticancer activity of the protein fraction against cancer cells.

\section{Acknowledgements}

The author thanks Mahdalia and Rini Prasetyawati for invaluable help and technical assistance, and the head of Biochemistry Laboratory of Hasanuddin University Indonesia for sample preparation and antioxidant and anticancer testings. The author also thanks Madhyastha Radha for editorial reading of the manuscript. This work was supported in part by BOPTN of Hasanuddin University and the Department of Education and Culture of Indonesia through Directorate General of Higher Education (DGHE) on Scheme Program for Academic Mobility and Exchange (SAME) Program Fiscal year 2014.

\section{References}

[1] A. Nontji, 2002, Archipelago Sea, Djambatan Publisher, Jakarta, pp. 4-6 and 145-147,

[2] R. Rachmat, 1999, Natural Products Utilization of Marine Algae for Drugs and Cosmetics, Paper presented at the VII Forum Communications Procedings Pra Kipnas I Physiology Association of Indonesia (IFI), Indonesian Institute of Sciences (LIPI), Serpong, 08 September 1999,

[3] World Health Organization, 2012, Cancer (online), http://www.who.int/mediacentre/factsheets/fs297/index.html, acces on October 05, 2012.

[4] I.C., Sheih, T.J., Fang Wu, T.K., Lin, 2010, Anticancer and antioxidant activities of the peptide fraction from algae protein waste. J Agric Food Chem. 58(2), pp.1202-1207.

[5] T. Sugahara, Y. Ohama, A. Fukuda, et al. 2001, The cytotoxic effect of Eucheuma serra agglutinin (ESA) on cancer cells and its application to molecular probe for drug delivery system using lipid vesicles, Cytotechnology. 36(1-3), pp. 93-99.

[6] S. Dali, H. Natsir, H. Usman, and A. Ahmad, 2011, Antibacterial Bioactivity Protein Fraction of Red Algae Gelidium amansii from Takalar Cikoang Aquatic, South Sulawesi, Pharmacy Magazine and Pharmacology, 15 (1): pp. 47-52.

[7] M. Hayes, (Ed). 2012, Marine Bioactive Compounds: Sources, Characterization and Applications. Springer-Science, New York, London.

[8] H.C., Schro"der, H., Ushijima, A., Krasko, V., Gamulin, N.L., Thakur, B., Diehl-Seifert, I.M., Muller, and W.E.G., Muller, 2003, Emergence and Disappearance of an immune molecule, an antimicrobial lectin, in basal metazoan. A TACHYLECTIN-RELATED PROTEIN IN THE SPONGE SUBERITES DOMUNCULA. J. Biol. Chem., 278, pp.32810-32817.

[9] O. H., Lowry, N. J., Rosebrough, A. L., Farr, and R. J., Randall, 1951, Protein Measurement with The Folin Phenol Reagent, J. Biol. Chem., 193: pp.265-275.

[10] Juniarti, D. Osmeli, and Yuhernita, 2009, Content of Chemical Compounds, Toxicity Test (Brine Shrimp Lethality Test) and Antioxidants (1,1-diphenyl-2-picrilhydrazil) from the Leaf Extract Saga (Abrus precatorius L.), Makara Sains, 13 (1): pp. $50-55$ 
[11] P. Molyneux, 2004, The use of stable free radical diphenylpicrylhydrazyl (DPPH) for estimating antioxidant activity, Songklanakarin J Sci Technol., 26 (2): pp. 211-219.

[12] N., Weerapreyakul, A., Nonpunya, S., Barusrux, T. Thitimetharoc, and B. Sripanidkulchai, 2012, Evaluation of the Anticancer Potential of Six Herbs against a Hepatoma Cell Line, Chinese Medicine, 7 (15): pp. 2-7.

[13] A. P. D., Nurhayati, N. Abdulgani, and R., Febrianto, 2006 , Toxicity Test of Eucheuma alvarezii Extract against Artemia salina as Potential Anticancer Preliminary Study, Indonesia Chemical Deed (Kimindo Deed), 2 (1): pp.41-46.
[14] S. D., Marliyana, F. W., Rakhman, H., Nestri, and R., Rakhmawati, 2012, Toxicity Test (Brine Shrimp Lethality Test) of Whole Extract from Pandanus conoideus L., Alchemy Jurnal Penelitian Kimia, 8 (1): pp. 24-33.

[15] B. N., Meyer, N. R., Ferrigni, J. E., Putman, L. B., Jacbsen, D. E., Nicols, and J. L. McLaughlin, 1982, Brine Shrimp : A Comvenient general Bioassay For Active Plant Constituents. Plant Medica. Pp.31-34.

[16] E., Johannes, Syafaraenan, R., Agus, dan R., Umar, 2013, Antimitotic activity of $\beta$-sitosterol Isolates from Hydroid Aglaophenia Cupressina Lamoureoux the Early Cleavage Cell Zygote of Urchin Tripneus tesgratilla Linn., MANASIR, 1 (1): pp. 27-32. 